\title{
Bireyve
}

Toplum

\section{“Gezi”nin Arkasındaki Siyasal ve Ekonomik Motivasyon}

\section{Musa ÖZTÜRK ${ }^{1}$}

Mesele sadece Gezi Parkı değil arkadaş, sen hâlâ anlamadın mı? Hadi gel. @memetalialabora, 30.05.2013 21: 45 Ölmek için daha güzel bir gün olabilir mi? İkinci kurtuluş mücadelesinin ilk şehitlerinden olmak var günün sonunda. @bhtyrngn 01.06.2013 06: 52

Öz: Gezi Parkı Eylemleriyle ilgili bugüne kadar yapılan çalışmalar genellikle güncel gerçeklikten hareketle ele alınmıştır. Bu çalışmada ise mesele; tarihin Avrupa ve Asya toplumları için farklı istikametlerde seyrettiği düşüncesinden hareketle tarihsel arka planı ve derinliği bağlamında ele alınmaya çalışılmıştır. Kapitalizm, I. Dünya Savaşıyla imparatorluk türü siyasal organizasyonları çözerek ulus-devlet anlayışını yaygınlaştırmış, II. Dünya Savaşıyla da siyasal bağımsızlıkların çoğunu ekonomik ve teknolojik bağımlılığa tahvil etmiştir. Ortaçağdan itibaren bozulan Doğu-Batı dengesinin Soğuk Savaş döneminin sonlarına doğru Asya toplumlarının kendilerini toparlamasıyla 21. Yüzyılda yeniden kurulmaya çalışıldığı görülmektedir. Türkiye’nin, özellikle 2002 sonrasında göstermiş olduğu "performansla" kalkınmada batılı standartlara yaklaşması ve IMF ile olan borçluluk ilişkisini sonlandırdığı haftayı takip eden bir dönemde Gezi Parkı Eylemlerinin

1 Yrd. Doç. Dr. Mardin Artuklu Üniversitesi Edebiyat Fakültesi Sosyoloji Bölümü, mmusaozturkk@gmail.com 
patlak vermesi asıl meselenin” üç beş ağaç” olmadığını göstermektedir. Dolayısıyla olayın siyasal motivasyonu bozucu etkisinden dolayı tarihsel arka planından hareketle ele alınması bizlere önemli açılımlar sağlayabilir.

Anahtar Kelimeler: Kapitalizm, Ulus-Devlet, Demokrasi, IMF, Faiz, Soğuk Savaş, Asya.

\section{Giriş}

Her disiplinin kendine özgü bir gündemi vardır. Çoğu zaman araştırmacı kendi çalışma evreni içinde kalmayı tercih ettiğinden güncel gelişmelere yabancılaşabilmekte veya güncel olanla ilgilenmeyi gereksiz bir uğraş olarak görebilmektedir. Bu tamamen araştırmacının takdirine kalmış bir durumdur. Akademinin gündeminden gündemin akademisine doğru gelmek, araştırmacıyı popülist söylemlere angaje olmak/kalmak gibi bir riskle karşı karşıya getirmektedir. Gündelik hayatın bize sunduğu veri bolluğu içinde boğulmadan, akademik birikimin yardımıyla onlar üzerinden bir çözümlemede bulunabilmek araştırmacının elini güçlendirir. Akademik bilgiyi gündelik gerçekliğe indirgemek, gündelik gerçekliği akademik bir bakış açısıyla ele alabilmek, konjonktürelgelişmeler üzerinden akademik bir literatür üretmek ya da konjonktürel gelişmeleri akademik bir bakış açısıyla değerlendirebilmek hiç de kolay bir iş değildir. Fakat bütün bu risklere rağmen yaşanan gelişmeler bize kendi içerisinde yeni bazı fırsatlar da sunmaktadır.

Hayat sürekli bir akış/oluş içerisinde olduğundan bizler bir yandan yeni fikirler edinirken diğer yandan daha önce edindiğimiz fikirler eskimektedir. A ğ teknolojileri vasıtasıyla anlık olarak her türlü bilginin üretilmesinin ve dağıtılmasının mümkün hale gelmesi bir yandan dezenformasyon ve tasnif sorunlarını beraberinde getirirken diğer yandan derinlemesine araştırmaların yapılmasını ketlemektedir. Gezi Parkı Eylemleriyle ilgili sosyal medyada, basın ve yayın organlarında pek çok haber yapıldığı gibi, akademik çalışmalarda kullanılabilecek bir veri bankasının da ağ üzerinden erişime açıldığı görülmektedir. Eylemleri takip 
eden günlerde/haftalarda/aylarda; $\mathrm{KONDA}^{2}$, GENAR 3 , $\mathrm{SETA}^{4}, \mathrm{SDE}^{5}$, TUSIVAR $^{6}$, TASAV $^{7}$, İKAV $^{8}$, MAZLUMDER $^{9}$, OrtadoğuAnaliz ${ }^{10}$, DİBAnaliz ${ }^{11}$, Uluslararası Af Örgütü ${ }^{12}$ veTürk Psikologlar Derneğ ${ }^{13}$ gibi kuruluşların süreci anlamaya yönelik araştırmalar ve raporlama çalışmaları yürüttükleri görülmektedir. Yapılan bütün bu çalışmalar değerlendirildiğinde çoğunun meseleyi içeriden bir bakış açısıyla ele aldığı ve alandan hareketle açıklamaya çalıştığı görülmektedir. Bu çalışmada mesele bunlardan farklı olarak; gündelik gerçekliğin hinterlandını oluşturan tarihsel arka plandan hareketle ele alınmaya çalışılacaktır. Dolayısıyla çalışma bu açıdan bir boşluğu doldurma gayesini gütmektedir.

Değişimin pek çok nedeni olabileceği gibi pek çok sonucu da olabilir. Doğası gereği sosyal olayların sonucunu önceden kestirilebilmek mümkün değildir. Hemen hemen hiç kimse Avusturya-Macaristan İmparatorluğu Veliahtı’nın bir Sırp milliyetçisi tarafından öldürülmesininI. Dünya Savaşını çıkaracağını, Tunuslu Muhammed Buazizi’nin kendini yakmasının Arap Baharı’nı başlatacağını, bazı aktörlerin sosyal medya vasıtasıyla paylaşımda bulundukları iletiler üzerinden Gezi Parkı Eylemlerinin ise kitleselleşeceğini öngöremez. Gündelik hayatın akışı içinde bunlar sıradan olaylardır çünkü her gün buna benzer sayısız olay cereyan etmektedir. Dolayısıyla bütün bunlarsembolik düzeyde tetikleyici faktörlerdir. Fakat asıl önemli olan bu tepkilerin beslendiği

2 http://t24.com.tr/files/GeziParkıFinal.pdf

3 http://www.genar.com.tr/files/GEZIPARKI_PROFIL-SON.pdf

4 ht t p://file.setav.org/Files/Pdf/20130916162138_ kurguilegerceklikarasindagezieylemleri_rapor

5 http:/www.sde.org.tr/userfiles/file/SDE\%20Taksim\%20Gezi\%20Park1\%20Raporu\%20 Haziran202013.pdf

6 http://tusivar.com/wp-content/upşoads/2013/09/BURSA-GEZİ-PARKIARAŞTIRMASI-pdf.pdf

7 http://tasav.org/usr_img/yayinlar/analiz/analiz_4_shy_4_gezi_parki_ylGIt_son.pdf

8 http://www.ikv.org.tr/images/upload/data/files/ikv_degerlendirme_notu-73.pdf

9 http://istanbul.mazlumder.org/webimage/gezi-parki-raporu-2013.pdf

10 http://www.orsam.org.tr/tr/trUploads/Yazilar/Dosyalar/201372_oanaliztemmuzder. pdf

11 http://dibakgenc.org/wp-content/uploads/2013/09/Gezi-Park...pdf

12 http://www.amnesty.org.tr/ai/system/files/GeziParkiTR.pdf

13 http://www.psikolog.org.tr/assets/file/pdf/DIRENTPD.pdf 
kolektifbilinçaltıdır. Bu düşünceden hareketle, mesele çevresel hassasiyetleri yüksek bazı insanların duyarlılığı şeklinde uç vermiş gibi görünse deolayların kısa süre içinde dalga dalga ülke çapında hükümeti protesto hareketlerine dönüşmesi, meselenin birkaç ağaç ya da çapulcu meselesine indirgenemeyecek kadar ciddi olduğunu göstermektedir.

Sosyal olaylardeğerlendirilirken nerede durup nasıl bakıldığına bağlı olarak değişik çıkarımlarda bulunulabilir. Yerel, içeriden, aşağıdan ya da tabandan yukarıya doğru yapılacak bir okumayla elde edilecek neticeyle; küresel, dışarıdan, üstten ya da yukarıdan bakarak elde edilecek netice arasında bir farkın olacağı muhakkaktır. Çalışmanın başlığı, eylemcilerin, eylemlerinin arkasındaki motivasyona dikkati çekmektedir. Bu çalışmada; Gezi Parkı EylemlerininAsya ve Avrupa toplumlarının tarihsel süreçte geçirmiş olduğu sosyo-ekonomik ve siyasal değişim süreçlerinden hareketle ele alınmasının bizlere önemli açılımlar sağlayacağı düşüncesinden hareketle; mesele tarihsel arkaplanından hareketle ele alınmaya çalışılacaktır.

\section{Tarihin Avrupa Merkezli Okunması:}

\section{Parçalı Yapılardan Bütüncül Yapılara}

Paul Kennedy, 1500'lü yıllarda Avrupa’nın durumunu şöyle özetlemektedir: Modern ve modern öncesi dönemleri birbirinden ayırmak üzere seçilen 1500'lü yıllar, Avrupa’nın dünyanın geri kalan yanı üzerinde egemenlik kurmaya hazır bir duruma geldiği, kıta sakinleri için hiç de belli olan bir şey değildir. O çağın insanlarının Doğunun büyük uygarlıklarına ilişkin bilgileri gezginlerin hikâyelerine dayandığından bölük pörçük ve çoğu kez de hatalıydı. Fakat bununla birlikte, çoğunluğun kafasında beliren olağanüstü zenginliklere ve kocaman ordulara sahip Doğu imparatorlukları imgesi, gerçeğe oldukça yakındır. Bu toplumlar, kendileriyle ilk kez karşılaşanlara, muhtemelen Batı Avrupa halkları ve devletlerine göre çok daha şanslı görünmüşlerdir. Gerçekten de bu büyük kültür ve ekonomi etkinlikleri merkezleriyle yan yana getirildiğinde, Avrupa’nın nispi zayıflıkları, kuvvetli yanlarından daha belirgin hale geliyordu. Her şeyden önce, Avrupa; dünyanın ne en bereketli, 
ne de en kalabalık bölgesiydi. Her iki bakımdan da Hindistan ve Çin başköşeyi alıyorlardı. Avrupa kıtası, jeopolitik açıdan, biçimsiz bir yapıya sahipti. Kuzey ve batıda buzla ve suyla sınırlanmış, doğusunda kara yönünden sık sık yapılan istilalara açık, güneyde ise stratejik tuzaklara karşı zayıftı. 1500'de ve bu tarihten çok daha önceleri ve sonraları, bunlar soyut düşünceler değildi (Kennedy, 1990: 3).“Avrupa’nın tarihi, özgürlüğün tarihidir” fikri, günümüz dünyasında pek az tarihçi tarafından kabul edilmesine rağmen İngilizce konuş/ul/an dünyanın Avrupa'nın geçmişini algılama biçimini sürdürmektedir (McNeill, 2011: 7). Ayrınt1lardaki büyük karmaşıklıklara karşın, Avrupa' da 1500-1648 yılları arasında politika alanında görülen gelişmelerin genel eğilimini kavramak güç değil. Ortaçağda yaygın olarak görülen çeşitli egemenlerin ve makamların yetki alanlarının birbiri içine girmiş olmasının yarattığı karmakarışık durumla karşılaştırıldığında, siyasi erkin daha az sayıdaki merkezde odaklaşma eğilimi gösterdiği anlaşılır (McNeill, 2008: 433)”.

$\mathrm{Bu}$ tespitlerden hareketle genel olarak Avrupa tarihinin kendi içerisinde Ortaçağdan itibaren feodal beyler, prenslikler, krallıklargibi küçük örgütlenmelerdenulus-devlet gibi daha büyük örgütlenmelere, siyasi organizasyonlara doğru bir değişim gösterdiği görülmektedir. Kutsal Roma Cermen İmparatorluğuna bağlı prensliklerin kendi siyasi gelecekleri için girmiş oldukları Otuz Yıl Savaşları sonucunda imzalanan Westfalya Barış Antlaşmasıyla (1648) Kutsal Roma Cermen İmparatorluğu küçük küçük devletlere ayrılarak Avrupa'da ulus-devlet sistemine geçilmiştir. Uluslaşmaya giden yolda burjuvazi başat bir rol oynamıştır.

"Ortaçağ burjuvazisi gibi tam anlamında(anlamıla) kentsel bir s1nıf daha önce hiç var olmamıştır." (Pirenne, 2011: 13). "Akışkan sermaye, iyi bir kimyasal çözücü olduğunu kanıtlamış, Ortaçağ kentini uzun süre korumuş olan cilanın çatlağından içeri sızdı ve ham ahşabı yiyip bitirmiş; tarihsel kurumların ve binaların ortadan kaldırılmasında en pervazsız mutlak hükümdarlardan daha acımasız olduğunu göstermiştir. İnsan bütün bu değişimi, Ortaçağ kentinin somut pazaryerinin yerine, kârlı bir işin yapılabileceği her yerde bitiveren soyut ulus-aşırı pazarın geçmesi şeklinde yorumlayabilir (Mumford, 2007: 502 - 503)”. 
Dolayısıyla bu, siyasal değişim ve dönüşüm sürecinin kapitalizm gelişimiyle paralellik arz ettiği görülmektedir."Şimdi içinde yaşadığımız dünyanın, modern dünya-sisteminin kökenleri 16. Yüzyıldadır. Bu dünya-ekonomi o zamanlar sadece yerkürenin bir parçasında, öncelikle Avrupa ve Amerika kıtasının bazı kısımlarında konumlanmıştı. Zamanla bütün yerküreyi kaplayacak şekilde genişledi,... (Wallerstein, 2005: 45)”. Matbuatın kapitalizmden nasibini almasıyla basılı malzemeler meta haline dönüşmeye başlamıştır ki bu eş zamanlı olarak toptan bazı yeni fikirlerin doğmasına yol açtığı gibi onların yayılmasını da kolaylaştırmıştır. Benjamin, 1500'lü yıllara gelindiğinde 20 milyon kitabın basılmış olduğundan bahsetmekte ve bu dönemi "mekanik yeniden üretim çă̆ı" olarak nitelendirmektedir (Anderson, 2007: 52). Berkes'in (2006: 37) tespitlerine göre; Fatih'in İstanbul'u kuşattığı (1453) sıralarda Gutenberg Avrupa’nın göbeğinde basacağı ilk kitabı hazırlamaktadır. Yalnızca 15. Yüzyılda Avrupa' da 1700 matbaanın kurulduğu, 15-20 milyon kitabın basıldığ tahmin edilmekte, 1500'de altmıştan fazla Alman şehrinde matbaa bulunmaktadır.

Ortaçağda ekonomik canlanışın belirgin özelliğini uzun mesafelere yapılan ticaret oluşturmaktadır (Pirenne, 2011: 93). Fransız İhtilaline (1789) kadar olan süreçte kendi içinde büyük ölçüde siyasi birliğini sağlayan Avrupa, burjuvazinin öncülüğünde diğer coğrafyalara ve özellikle de Asya’ya doğru bir yayılma sürecine girmiştir. Burjuva ideolojisi milliyetçiliğin, batı dışı coğrafyalara doğru servis edilmesiyle çok dinli, dilli, kültürlü siyasal organizasyonlar çözülme riskiyle karşı karşıya kalmışlardır. Mesela; "Osmanlı millet sistemi Westfalya sisteminin hem siyasî değerler ve ilkeler, hem de mekanizmalar açısından bir alternatifini teşkil etmektedir. Batı medeniyetinin tarihî serüveninin ürünü olan Westfalya sistemi ve bu sistemle özdeşleşen merkantilist ekonomik yapılar, Osmanlı millet sistemi ve bu sistemin dayandığı ekonomi-politik yapının zıddıdır. Bu sebepledir ki ikincisi egemen olduğunda birincisini Avrupa'nın bir köşesine mahkûm etmiştir; birincisi egemen olduğunda ise ikincisini çözen bir süreci başlatmıştır (Davutoğlu, 1999: 59)". 
Westfalya Barış Antlaşmasıyla Otuz Yıl Savaşlarını sona erdiren Avrupa, kendi içerisinde siyasi çatışmaları ulus-devlet modeline geçmekle büyük ölçüde çözmüştür. Dolayısıyla "Modern demokrasi, köy, kabile veya şehir devletleri demokrasisinden ibaret değildir, milli devletlerin demokrasisidir ve ortaya çıkışı milli devletlerin gelişmesiyle bağlantılıdır (Huntington, 2007: 10)”.Merkantilist dönemde değerli madenlerin Avrupa'ya taşınmasıyla, kalkınmanınmaliyeti sömürge ülkelerine ödettirilmiştir. Ulus-devlete geçişin beraberinde getirmiş olduğu siyasal istikrar ve ekonomik güven; Adam Smith'inMilletlerin Zenginliği(2011) kitabında gayet iyi bir şekilde formüle ettiği işbölümü ve üretim art1şının beraberinde getirdiği rekabet üstünlügüne dayalıyeni bir ekonomik dönemi başlatmıştır. Teşebbüs hürriyeti kılıfı altında liberalizmin ve milliyetçiliğin kapitalizm üzerinden batı dışı coğrafyalara taşınması; bugün ekonomik gelişmişlik endeksi açısından üçüncü dünya ülkesi olarak nitelendirilen pek çok ülkenin sömürgeleştirilmesine ${ }^{14}$, o günün büyük siyasal organizasyonlarının da parçalanarak günümüzulus-devletlerine dönüşmesine yol açmıştır.

\section{Tarihin Asya Merkezli Okunması:}

\section{Bütüncül Yapılardan Parçalı Yapılara}

Avrupa'nın modern dönemlere kadar dünya siyasetinde ve kültür hayatında büyük bir etkisinden söz edilemez. "Asya’nın büyük uygarlıklarıyla karşılaştırıldığında Avrupa'nın; kültür, matematik, mühendislik alanları ya da gemicilik teknolojisi ve diğer teknolojiler açısından belirgin üstünlüklerinin olduğu söylenemezdi. Avrupa’nın kültür ve bilim birikimin oldukça büyük bir bölümü zaten İslam dünyasından "ödünç alınmıştı”. Tıpkı Müslüman toplulukların yüzyıllar boyu karşılıklı ticaret, fetihler ve yerleşim yoluyla Çin'den aldıkları gibi. Geriye dönüp bakıldığında, Avrupa'nın 15. yüzyılın sonlarında, gerek ticaret gerek teknoloji açıdan hız kazandığı görülebilir. Ancak o dönemle ilgili olarak

14 Ayrıntılı bilgi için bak. RaimondoLuraghi, Sömürgecilik Tarihi, Çev. Halim İnal, E Yayınları, İstanbul 2000 ve MarcFerro, Sömürgecilik Tarihi, Çev. MunaCedden, İmge Kitabevi, Ankara, 2011. 
yapılabilecek en doğru genelleme belki şu olabilir: O sıralarda büyük dünya uygarlık merkezlerinden her biri aşağı yukarı benzer bir gelişme aşamasında bulunuyor, kimileri bir alanda daha ileri başka alanda daha geri olabiliyordu. Teknolojik ve buna bağlı olarak da askeri açıdan Osmanlı İmparatorluğu, Ming Hanedanı yönetimindeki Çin, biraz daha sonra da Moğol egemenliğindeki Kuzey Hindistan, Avrupa devletler sistemi ve bu sistemin Moskof Rusya'sındaki uzantısı, hep Afrika, Amerika ve Okyanusya’nın dağınık toplumlarından çok daha üstün durumdaydılar. Bütün bunlar, Avrupa’nın 1500 yılında en önemli kültürel güç merkezlerinden biri olduğuna işaret etse de Avrupa’nın günün birinde tepeye çıkacağ 1 hiç de belli olmuyordu (Kennedy, 1990: 4)”.

19. Yüzyılın büyük siyasal organizasyonları olan Osmanlı Devleti, Avusturya-Macaristan İmparatorluğu, Prusya Krallı̆̆ı, vb. siyasal organizasyonların 20. Yüzyılın başlarında hemen hepsinin dağıldığı ve bugünün ulus-devletlerin bu miras üzerinde yükseldiği görülmektedir. Tilly (2001: 275) bu durumu son bin yılın başat siyasal olgusu olarak değerlendirmektedir. Asya merkezli tarih anlayışı üzerinden bir okuma yapıldığında ise, Avrupa tarihinin aksine tarihin akışının farklı bir istikamette seyrettiği görülmektedir. Ulus-devlete geçiş sürecinde Avrupa tarihi parçalı yapılardan bütünleşmeye doğru bir çizgi takip ederken Asya tarihi bütüncül yapılardan parçalanmaya doğru bir seyir takip etmiştir. Ulus-devlet sisteminin Avrupa-dışı alanlara doğru yaygınlaşması, bu yapı ile yeni yeni tanışan Avrupa-dışı toplumların siyasal kültür ve kurumsallaşma problemlerinin derin etkisini yaşayarak devletleşme sürecine geçmelerine yol açmıştır (Davutoğlu, 2002: 18). Ulus-devlete geçişle - uluslaşmaya giden yolda - karşılaşılan problemlerin kapitalizm üzerinden okunması, bugün yaşanan süreci anlamlandırmamıza imkân vermesi açısından önemlidir. Wallerstein'de belirttiği gibi kapitalizm doğası gereği, kendi işleyişine ve sermayenin serbest dolaşımına müdahale edecek - ya da etme potansiyeli barındıran - büyük ölçekli siyasal organizasyonlardan hoşlanmaz. Aksine,sermaye giriş-çıkışlarına minimum düzeyde direnecek, geçirgen küçük çaplı siyasal organizasyonları ve ulus-devletleri zorunlu kılar. Kapitalist sistem, strateji gereği büyük çaplı siyasal organizasyonların parçalanmasını ve ekonomik açıdan 
kontrol edilebilir bir düzeyde/büyüklükte tutulmasını gerekli kıldığından, kapitalist üretim ilişkilerinin ve pazarlama stratejilerinin gelişim tarihi büyük ölçekli siyasal organizasyonlardanulus-devlete geçişin tarihiyle örtüşmektedir.

Mesela; kendi tarihimizden örnek vermek gerekirse; Fatih Sultan Mehmed tarafından ilk defa Venediklilere verilen kapitülasyonlar, süreç içerisinde Fransa, İngiltere başta olmak üzere diğer birçok ülkeye de verilmiştir. Kapitalist iktisat anlayışı ihtiyaçların çoğaltılması, tüketim ve israf üzerine kurgulanırken; Osmanlı ekonomi anlayışı modern kapitalist mantığın aksine ihracattan ziyade ithalat üzerine kurguland1ğından ve hatta ihracatın ülke içinde yoksullaşmaya yol açacağ 1 gerekçesiyle yüksek vergi oranlarıyla engellenmeye çalışıldığından (Mardin, 2003: 111), o günkü şartlarda kapitülasyonların verilmesinde bir sakınca da görülmemiştir. Dahası verilen ilk imtiyazların o günün şartları gereği hem siyasi/diplomatik hem ekonomik hem de dini açıdan devletin menfaatine olduğu görülmektedir.

Merkantilizmin ateşlediği kapitalizmin hızla Avrupa’nın doğusuna doğru genişlediği/yayıldığı bir dönemde İngiltere’yle imzalanan Balta Limanı Ticaret Anlaşmasıyla (1838) Osmanlı Devleti resmen batının açık pazarı haline gelmiştir. Ahmet Güner Sayar’ın(2013) da belirttiği gibi, "iktisadi rasyonalite eksikliği”nden dolayı süreç Osmanlının aleyhine işlemiştir. Diğer bir ifadeyle mesele, batı ve doğu toplumlarının iktisat mantığının/mantalitesinin farklılığından kaynaklanmaktadır. Başlangıçta devletin lehine olan kapitülasyonların süreç içerisinde devletin aleyhine bir sürece doğru evrildiğinin fark edilmesiyle; sanayiyi güçlendirmeye ve üretim artışını canlandırmaya yönelik bir kısım teşviklerde bulunulsa da başarılı olunamaz. Savaşların yenilgilerle sonuçlanması, toprak kayıplarının artması, vb. nedenlerin etkisiyle ekonomik krizhızla derinleşerek devlet borca batmış ve batılı ülkeler Duyun-u Umumiye (1881) ${ }^{15}$ idaresi üzerinden devletin gelirlerine el koymuşlardır. Devletin ekonomik açıdan batılı ülkelerin açık pazarı haline gelmesi,

15 Ayrıntılı bilgi için bak. Doğan Avcıoğlu, Türkiye’nin Düzeni, Cilt: I. Tekin Yayınevi, İstanbul, 1995, s. 126-134. 
balkanlarda Osmanlı egemenliğinin başından beri özü var olan ve Osmanlı modernleşmesini hızlandıran ulusçuluk akımlarının ${ }^{16}$ geri püskürtülerek, bu tür taleplerde bulunanlara yeni meşruiyet alanları açmasının önünü tıkamıştır.

Toprak kayıplarının artmasıyla Osmanlının kontrol ettiği siyasal alan hızla daralmış ve 20. yüzyılın ilk çeyreğinde, dünyadaki siyasal gidişata uygun olarak ulus-devlet şeklinde örgütlenmek kaydıyla ancak Anadolu coğrafyası elde tutulabilmiştir. "I. Dünya Savaşı neticesinde gerçekleşen sömürgeci bölüşümle bölgenin asırlardır süren ve son olarak da Osmanlı Devleti tarafından daha geniş kapsamlı bir bütün içinde muhafaza edilen İslam Medeniyeti kimliği etrafında şekillenmiş jeokültürel ve jeopolitik karakteri parçalanmıştır. Bölgenin Müslüman toplulukları arasındaki çatışma unsurları tahrik edilerek bölgenin ekonomik kaynakları sömürgeci güçlerin operasyonlarına uygun hale getirilmiştir (Davutoğlu, 2003: 339)”.

I. Dünya Savaşı sonunda Osmanlı Devletinin dağılmasıyla Balkanlarda, Kafkaslarda ve Ortadoğu' da yeni ulus-devletler kurulmuştur. Dağılmaya doğru giden süreçte toprak kayıplarının artmasına paralel olarak özellikle Balkanlardan ve Kafkaslardan çok sayıda Müslüman ve Türk unsur Anadolu'ya göç etmiştir. Tanzimat'tan itibaren adım adım takip edilen Osmanlıcılık, İslamcılık stratejilerinin tutmamasına ve ayrılıkçı eğilimlerin artmasına paralel olarak Türkçü anlayış yükselmiştir. Osmanlı devlet bürokrasisindeki Türkçü anlayış II. Viyana Kuşatmasından sonra devşirme usulünün terk edilmesiyle öne çıkmaya başlasa da o günkü şartlar bağlamında düşünüldügüunde bunun milliyetçi ve ayr1lıkçı bir karakterde olduğu söylenemez (Ortaylı, 2005: 59).

Sanayileşmesini tamamlamış, hammadde ve pazar arayışı içerisindeki kapitalizmin merkez ülkelerinin yayılmacı stratejilerine karşı İslam kardeşliği şemsiyesi altında ümmetçi bir şuurla verilen bağımsızlık mücadelesi sonucu Osmanlı topraklarından ancak Anadolu coğrafyası kurtarılabilmiştir. Misak-ı Millî sınırları içinde yaşayan unsurların kolektif

16 Ayrıntılı bilgi için bak. İlber Ortaylı, İmparatorluğun En Uzun Yüzyılı, Alkım Yayınları, İstanbul, 2005, s. 57-86. 
mücadelesi sonucu kurulan Türkiye Cumhuriyeti, TBMM'nin almış olduğu kararlarla önce saltanatı (01 Kasım 1922) ve ardından da halifeliği (03 Mart 1924) kaldırmıştır. Özellikle halifeliğin kaldırılması Kurtuluş Savaşı ruhunu motive eden ana damarın kesilmesine ve Anadolu coğrafyasının İslam dünyasıyla olan ilişkilerinin kopmasına, Türkiye'nin İslam dünyasına/ülkelerine yabancılaşmasına yol açmıştır. Osmanlıyla siyasi ve dini bağların koparılmasından doğan boşluk, çağın ruhuna uygun olarak etno-seküler Türk kimliğiyle doldurulma yoluna gidilmiştir ${ }^{17}$.

Cumhuriyetin kurucu elitleri, uluslaşmanın önündeki engelleri kaldırmak için bir yandan nüfus mübadelesiyle Anadolu’yu Rumlardan arındırırlarken ${ }^{18}$ diğer yandan da Kürtlerin asimilasyon yoluyla Türkleştirilmeleri çalışmalarına hız verilmiştir. Bu uygulamalara tepki olarak Cumhuriyetin kuruluşundan itibaren II. Dünya Savaşına kadar olan yıllarda başta Şeyh Sait İsyanı olmak üzere birçok Kürt isyanı çıkmış ve bunlar oldukça sert önlemlerle bastırılma yoluna gidilmiştir. ${ }^{19}$ Dolayısıyla bugün Türkiye'de yaşanan Kürt sorununun kökeni çoğulcu bir siyasi yapıdan tekçi/tekil bir siyasi yapıya geçişten kaynaklanmaktadır.

Büyük devletlerin klasik ulusal stratejilerini geliştirdikleri 19. yüzyılda Osmanlı Devleti iç bütünlüğünü muhafaza etmeye ve toprak kaybetmemeye odaklanmıştır. Sınır hatları boyunca savunma stratejisine dayanan statik yaklaşım zamanla dış politika geleneği niteliği kazanmıştır (Davutoğlu, 2003: 52). Önce saltanatın ardından da halifeliğin kaldırılmasıyla tarihi ve kültürel mirasına sırt dönen Türkiye siyasi, ekonomik, kültürel vb. açılardan kendisine ve çevresine yabancılaşmış ve Soğuk Savaş sonrası döneme Suriye, Yunanistan, Irak, Rusya gibi komşularıyla düşman olarak girmiştir. "Türkiye’nin yakın komşularıyla olan ilişkilerinin sürekli gergin tutulması, kâh Kuzey Irakta olduğu gibi iç savaşla, kâh İran'la olan ilişkilerde olduğu gibi ideolojik gerekçelerle, kâh Yayınları, İstanbul, 2010.

181915 Ermeni Tehciriyle, Ermenilerin genel nüfus yoğunluğu içerisindeki sayıları azaldığından Osmanlıdan Cumhuriyete önemli sayıda bir Ermeni nüfusu intikal etmemiştir.

19 Ayrıntılı bilgi için bak. Hüseyin Yayman, Türkiye’nin Kürt Sorunu Hafızası, Doğan Kitap, 2011, s. 483-493. 
Suriye örneğinde olduğu gibi arızî bunalımların kronikleştirilmesi suretiyle istikrarsızlaştırılması da aslında dolaylı olarak Türkiye'yi sınırlarına hapsederek kontrol altında tutmaya yöneliktir (Davutoğlu, 2003: 146)”.

"Sanki bir doğa kanunuymuş gibi her yüzyılda tüm uluslararası sistemi kendi değerlerine göre yeniden biçimlendirecek kuvvet, irade, entelektüel ve moral güce sahip olan bir ülke ortaya çıkmaktadır (Kissinger, 2009: 9)". I. Dünya Savaşından sonra İngiltere'den boşalan “alan” Amerika tarafından doldurulmuştur. Kissinger'e göre, "Amerika uluslararası arenaya girdiği zaman yeniydi, kuvvetliydi ve uluslararası ilişkilere bakış biçimini dünyaya kabul ettirme gücü vardı. 1945’te II. Dünya Savaşı son bulduğunda, Amerika o kadar güçlüydü ki (bütün dünya ekonomik üretiminin yüzde otuz beşi Amerika'ya aitti) dünyaya, kendi tercihlerine göre şekil vermesi kaçınılmaz görünüyordu (2009: 11)".Huntington, demokrasinin dalgalar halinde yayıldığını ileri sürmektedir. Buna göre, ikinci demokratlaşma dalgası, II. Dünya Savaşıyla başlamıştır. Müttefiklerin işgali, batı Almanya, İtalya, Avusturya, Japonya ve Kore'de demokratik kurumların kurulmasını teşvik etti ve 1940'ların sonlarılya 1950'lerin başlarında Türkiye ve Yunanistan demokrasiye yönelmişlerdir (Huntington, 2007: 15).

Savaşı, ABD’nin başını çektiği demokrasi cephesinin kazanmasıyla dünya; kapitalizm ve sosyalizm arasında kısa süreli bir rekabetin yaşandığı Soğuk Savaş dönemine girmiştir. Türkiye, tercihini savaştan galip ayrılan kapitalist ve demokratik bloktan yana kullanarak Rusya'ya karşı ABD ve İngiltere'nin yanında yer almıştır. Savaş sonrasında; dünyada demokrasi dalgası yükselmeye başlamış, pek çok sömürge ülkesi bağımsızlıklarına kavuşmuş ve Türkiye de uluslararası konjonktürün zorlamasıyla tek parti yönetiminden çok partili hayata geçmiştir. Dolayısıyla Türkiye'de demokrasi, devlet geleneğinin bir uzantısı olarak aşağıdan değil yukarıdan, halktan değil seçkinlerden gelen talep doğrultusunda şekillenmiştir.

\section{Siyasal Bağımsızlığın Ekonomik Bağımlılığa Tahvili}

Kapitalizmin gelişimiyle, ulus-devlet ve demokrasi arasında güçlü bir ilişki vardır."Pazar, bir serbestleşme, bir açılım, başka bir dünyaya 
giriştir. Bu yüzeye çıkmaktır. İnsanların faaliyetleri, mübadele ettikleri artık ürünler, yavaş yavaş bu dar çatlaktan geçmektedirler. Bu geçiş başlangıçta, Kitabı Mukaddes'teki deveyi iğne deliğinden geçirmek kadar zor bir iştir. Sonra delikler genişlemekte, çoğalmakta, toplum da koşunun sonunda, "genelleşmiş bir pazar toplumu" haline gelmektedir (Braudel, 2004: 14)".Huntington, demokrasinin dalga dalga yayıldığını belirtmektedir. Onun yapmış olduğu tasnife göre 1750'lerde Batı dünyasında ulusal düzeyde hiçbir demokratik kurum yoktur. Fakat 1900'lü yıllara gelindiğinde bu kurumlar artık pek çok ülkede mevcuttur. 20. yüzyılın sonlarına gelindiğinde ise çok daha fazla sayıda ülkenin demokratik kurumları vardır. Bu kurumlar; birinci, uzun demokratlaşma dalgası 1828-1926, birinci ters dalga 1922-1942, ikinci, kısa demokratlaşma dalgası 1943-1962, ikinci ters dalga 1958-1975, üçüncü demokratlaşma dalgası 1974'le gittikçe yayılmaktadır. Bu sistem içerisinde bir demokratlaşma dalgası, belli bir zaman dönemi içinde demokratik olmayan rejimlerden demokratik rejimlere doğru gerçekleşen ve aynı zaman dönemi içinde aksi yöndeki geçişlerden çok daha fazla sayıda olan bir grup geçiştir (2007: 10 - 11).

Kapitalizm, ideal düzeyde ancak demokratik ülkelerde işleyebilmektedir. "Uluslararası ekonomi-politiğin belirleyici üst kurumu olan G-8 sistemi ile uluslararası siyasi ilişkilerin teorik belirleyici üst kurumu olan BM Güvenlik Konseyi arasındaki (Davutoğlu, 2003: 77)” oligarşik ilişkiye bakıldığında kapitalizm ve demokrasi ikilisinin gayet güçlü bir koalisyon oluşturduğu görülmektedir. Kapitalizm ve demokrasi arasında doğru orantı olup, dünyanın en gelişmiş ülkeleri, demokrasinin en güçlü ve dayanıklı olduğu ülkeler kapitalist sistemin en güçlü olduğu ülkelerdir. Burada demokrasinin en adaletli yönetim sistemi olduğu yanılgısına düşmemek gerekmektedir.

Demokrasi, aslında belli aralıklarla yapılan seçimler yoluyla eşitsizlikleri onayladı̆̆ımız bir yönetim sistemidir. Kapitalizm doğası gereği zenginlik üretmekte çok mahirdir. Sistem, hegemonyasını eşitsizlikleri arttırarak devam ettirme üzerine kurmuştur. Sömürü düzeninin devamını ve meşruiyetini sağlama adına seçimler bir araç olarak kullanılmaktadır. 
Seçimler üzerinden eşitsizlikler belli aralıklarla onaylanmaktadır. Gramsci, egemen sınıfların bağımlı sınıflar üzerinde zor ve ikna yöntemleri kullanarak bütünlüklü bir otorite, egemenlik kurduklarına işaret etmektedir. Rızanın kazanılması veya çoğunluğun ikna edilmesi esas olarak üst yapı kurumları aracılığıyla gerçekleştiğinden kültürel alan oldukça önemli bir hegemonik mücadele alanıdır. Hegemonyanın oluşması için geniş halk kesimlerinin çıkarları ve değerlerine yönelik taviz verilmesi veya egemen sınıfın fikirlerinin değişikliğe uğraması gerekse de bu sürecin sonunda egemen sınıfların çıkarlarını sürdüren ve meşrulaştıran fikirler ve değerlerin önemli bir bölümü "tarafsız", "kaçınılmaz” ya da "evrensel” fikirler ve değerler olarak kabul edilmektedir (Gökalp, 2009: 120).Wallerstein'in aksine Braudel (2004: 542) kapitalizmi salt bir ekonomik sistem olarak tanımlamamakta ve Gramsci'nin işaret ettiği noktaya dikkati çekmektedir. Ona göre; "Hataların en kötüsü, kapitalizmin yalnızca bir "ekonomik sistem" olduğunu savunmaktır, oysa kapitalizm toplumsal düzen sayesinde yaşamakta, devletin hasmı veya işbirlikçisi olarak, onunla birlikte işleri karıştıran bir kişidir ve bu hep böyledir; kültürün toplumsal yapının sağlamlığına getirdiği tüm desteklerden de yararlanmaktadır çünkü eşitsiz paylaşılan, çelişkili akımlara yuva olan kültür, sonuçta her şeye rağmen en iyi unsurlarını kurulu düzenin desteklenmesi yönünde kullanmakta; onu savunurken kendilerini savunan egemen sinıfları tutmaktadır."

20. yüzyılın ilk çeyreğinde siyasal konjonktürün zorlamasıyla ölçek küçülterek imparatorluktan ulus-devlete geçen Türkiye, Cumhuriyetin ilk yıllarında gerçekleştirilen millileştirme ve kamulaştırma projelerine ilave olarak, ekonomide devletçilik ilkesini hayata geçirerek planlı ekonomi ve KİT’ler üzerinden kalkınmayı örgütlemeye çalışmıştır. II. Dünya Savaşında denge siyaseti takip ederek, savaşa girmemeye ve tarafsız kalmaya çalışmıştır. Yeni dönemde dışa açıklığın bir kural olarak dayatılması sonucu ticaret dengeleri azgelişmiş ülkeler aleyhine bozulmuştur. Bozulan dengeler strateji gereği bu ülkelerin IMF’ye borçlandırılarak sistem içinde tutulmasıyla aşılmaya çalışılırkendiğer yandan borç/luluk üzerinden hegemonik ilişki devam ettirilmektedir. Kriz dönemlerinden sonra IMF’nin gelmesi tesadüfi değildir. Bugünden geriye 
dönüp baktığımızda Demokrasi Tarihi açısından en istikrarlı yıllar, 1950-1960, 1983-1991, 2002 ve sonrası güçlü hükümetlerin işbaşında olduğu yıllardır. 1960-1980-1991-2002 arası yıllar, Türkiye'nin koalisyon hükümetleri tarafından yönetildiği siyasi istikrarsızlık yıllarıdır. IMF ile en çok stand-by anlaşmasının koalisyon hükümetleri dönemlerinde yapıldığı görülmektedir.

Siyasal istikrarsızlıkla, borçluluk ve ekonomik bağımlılık arasında doğrusal bir ilişkinin olduğu görülmektedir. Türkiye, 1947 yılında tek parti iktidarı döneminde IMF'ye katılan ilk ülkeler arasında yer almaktadır (Karluk, 2013: 71). Türkiye 1947 yılında IMF’ye üye olsa da ne tek parti ne de Demokrat Parti iktidarlarıdöneminde IMF ile herhangi birstand-by anlaşmasının yapılmadığı görülmektedir. Türkiye'nin IMF ile yaptığı anlaşmalara bakıldığında bunların siyasal istikrarsızlık sonucu yükselen ekonomik kriz dönemlerine karşılık geldiği görülmektedir. Mesela; ilkstand-by anlaşması 1 Ocak 1961'de yapılmış ve 31 Aralık 1961'de sona ermiştir. Türkiye’nin Avrupa Birliği ile ilişsilerinin başlaması da IMF ile stand-by düzenlemelerinin başladığı döneme rastlamıştır. 30 Mart 1962'de IMF ile yeni bir düzenlemeye giden Türkiye'nin bu anlaşması bir yıldan da az sürmüş ve 31 Aralık 1962' de bitmiş, 15 Şubat 1963'de imzalanan üçüncü stand-by ise yaklaşık dokuz ay sürmüştür. Dördüncü stand-by, 15 Şubat 1964 - 31 Aralık 1964 tarihlerini kapsamıştır. Türkiye, 1961 yılından, 1970 yılına kadar her yıl, IMF ile bir stand-by gerçekleştirmiş ve anlaşmalar genellikle bir yıl dolmadan sona ermiştir (Karagöl, 2013: 21).

"1960-1970 döneminde tüm yıllarda IMF ile anlaşma yapılmıştır(Karagöl, 2013: 6)".1950'de DP’nin iktidara gelmesiyle başlayan kalkınma hamlesi, siyasi istikrarsızlık dönemlerinde inkıtaa uğramış, Türkiye kendi iç meseleleriyle uğraşırken dış dünyaya yabancılaşmıştır. Türkiye'nin askeri vesayet altına girdiği 60’lı ve 70’li yıllar, kapitalizmin makas değiştirdiği döneme karşılık gelmektedir. Kapitalist dünya fordizmdenpostfordizme geçerek dışa doğru patlarken, Türkiye; 1968 öğrenci olaylarının tetiklediği ideolojik çatışmaların gündem yoğunluğu altında kalkınma ve kimlik problemlerini sağlıklı bir şekilde tartışamadan, 70’li yılları 
koalisyon hükümetleri ve Kıbrıs tartışmalarıyla geçirerek ideolojik kutuplaşmaların beslediği şiddet iklimi altında 12 Eylül 1980'e girmiştir.

1980'lerin ortalarına gelindiğinde demokrasiye geçişler, demokrasinin geleceği hakkında yeni bir iyimserlik dalgası yaratmıştı. ZibigniewBrezinski’nin "büyük iflas" olarak nitelendirdiği bu durumu, diğerleri daha da ileri götürerek; "yaşayabilir sistematik alternatiflerin tükenmesi, ekonomik ve siyasal liberalizmin tereddütsüz zaferi” şeklinde yorumlamışlardır (Huntington, 2007: 23). Komünist dünyanın kapitalist dünya gibi kendi içerisinde çeşitliliği üretememesi sonucu Soğuk Savaş döneminde kurulan denge kapitalist dünya ve onun temsil ettiği demokrasi, liberalizm, vb. "değerler" lehine bozulmaya başlamış ve 1989 yılında Rusya’nın dağılmasıyla Soğuk Savaş sona ermiştir. Rusya'dan doğan boşluk, Çin, Hindistan, Japonya, vb. yeni kutup başları tarafından doldurulmaya başlanmıştır.

Soğuk Savaş döneminde Türkiye tek kutuplu bir politika takip etmeye angaje olduğundan savaş sonrası döneme hazırlıksız yakalanmış, Türkiye’nin dolduramadığı boşluklar, ABD, Rusya, Çin, İran, vb. ülkeler tarafından doldurulmuştur. Türkiye, uluslararası konumdan çok, sınır/ lar boyu güvenlik anlayışına dayalı bir dış politika ve askeri strateji/ler oluşturmuş ve uluslararası konumunu bu güvenlik anlayışının dar kapsamı içinde yorumlamaya çalışmıştır (Davutoğlu, 2003: 73).

ABD’nin öncülüğünde uluslararası sistemin yeniden kurulduğu bu dönemde teorik zeminini Francis Fukuyama’nın oluşturduğu 'Tarihin Sonu" teziyle bir yandan kapitalizmin ve liberal demokrasinin zaferi kutlanırken diğer yandan komünizmden doğan boşluk İslam'la doldurulma yoluna gidilerek, Samuel P. Huntington'un “Medeniyetler Çatışması" tezi üzerinden İslam Dünyası hedef tahtasına konulmuştur. "Soğuk Savaş sonrası dönemde, bunalımların ve çatışmaların İslam Dünyasında (veya daha doğrusu Müslümanların yaşadığı dünyada) yoğunlaşmasının nedeni İslam Medeniyetinin ve Müslümanların bir karşı-kutup oluşturması değil, bu dünyanın sahip olduğu jeopolitik, jeokültürel ve jeoekonomik özelliklerdir (Davutoğlu, 2003: 254)”. Bu dönemde Türkiye; bir yandan terör sorunuyla boğuşarak demokrasiye doğru yol almak isterken diğer 
taraftan halkı Müslüman bir ülke olması dolayısıyla düşman saflarına doğru itilerek uluslararası sistemden tecrit edilmekle karşı karşıya kalmıştır. 11 Eylül saldırıları sonrasında İslam’ın şiddet ve terörizmle özdeşleştirilmesiyle uluslararası sistemden dışlanmaya çalışılan Türkiye, 2001 kriziyle daha güçlü bir şekilde IMF’nin kontrolüne girmiştir/alınmiştır.

Türkiye, 1961-2005 arası dönemde ortalama her 2,5 yılda bir Fon ile destekleme düzenlemesine gitmiştir. Türkiye, IMF ile en fazla destekleme düzenlemesi yapan Filipinler, Panama, Uruguay, Ekvator, San Salvador, Fas ve Kosta Rika gibi ülkeler kategorisinde bulunmaktadır (Karluk, 2013: 71). Çoğu ülke, bu kısır döngüden çıkamamakta ve her geçen gün daha ağır bir borç yükü altına girerek borçluluk üzerinden bağımlılıkları sürekli kılınmaktadır.Türkiye de uzun yıllar borç kumpasından çıkamamış ve IMF’nin daimi müşterilerinden biri olmuştur.

Türkiye, 2013 Mayıs ayında IMF'ye olan borcunun son taksitini ödeyerek 52 yıl aradan sonra IMF'siz olarak yoluna devam etmeye karar vermiştir. Borcunu kapatmasıyla Türkiye, önümüzdeki dönemler için IMF'ye kredi sağlayan ülkeler grubunda yer alacaktır. IMF'yle uzun yıllardır birlikte çalışan yukarıdaki ülkelerin ekonomik performansları ve hayat standartları kapitalizmin merkez ülkeleriyle mukayese edildiğinde fark ortadadır. Dahası pek çoğumuz haritada bu ülkelerin yerlerini bulmakta epey zorlanırız. Demokrasi ile kalkınmışlık düzeyi arasında pozitif bir ilişki vardır. Gezi Parkı Eylemlerinin Türkiye'nin IMF'yle 52 yıldır sürdürmüş olduğu borçluluk ilişkisini sonlandırdığı 17 Mayıs 2013 tarihini takip eden haftalarda patlak vermesi zamanlama açısından önemlidir.

\section{Siyasal İstikrar, Bağımlılıktan Kurtulma ya da Dengenin Yeniden Kurulması}

2002 seçimlerinde hükümeti oluşturan siyasi partilerin (DSP, ANAP, MHP) seçim barajı engeline takılarak meclis dışında kalmaları ve AK Partinin büyük bir çoğunlukla meclise girmesi hem siyaset kurumunun yeniden itibar kazanmasını hem de siyasi istikrarın yakalanmasını 
beraberinde getirmiştir. Burada şöyle bir yanılgıya düşmemek gerekmektedir: Siyasi istikrarla ekonomik istikrar arasında mekanik bir ilişki yoktur. Yoksa totaliter ülkeler siyasi açıdan en istikrarlı ülkelerdir ama ekonomik açıdan en gelişmiş ülkeler değildirler.

Siyasi istikrarın iyi yönetimle birleşerek oluşturmuş olduğu sinerjinin ekonomik istikrara dönüşmesi orta vadede enflasyon ve faiz oranlarının gerilemesini beraberinde getirmiştir. Enflasyonun düşmesine paralel olarak faiz oranlarının düşmesi; bir yandan devletin daha düşük faiz oranlarıyla borçlanmasınısağlarken diğer yandan da faizi cazip bir gelir kaynağı olmaktan çıkardığından, enflasyonist ortamda riske girmeksizin faize yatırılarak yüksek getiri elde edilebilecek olan paranın reel sektöre ve yatırıma gitmesinin yolunu açmıştır. Üretim artışının beraberinde getirmiş olduğu fiyat istikrarı ve ihracatın büyümeye olan pozitif etkisi GSMH'nin yükselmesini beraberinde getirmiştir.

Faizden tasarruf edilen kaynağın değişik kalemler altında ülke genelinde yürütülen yatırımların finansmanına transfer edilmesi genel anlamda refah seviyesinin yükselmesini beraberinde getirmiştir. Refah seviyesindeki artışın gelir dağılımındaki adaletsizliği "bastırmasının" bir sonucu olarak halkın siyasete olan ilgisi ve hükümete olan desteği her seçimde artarak devam etmiştir. Türkiye'nin siyasal istikrar ve ekonomik kalkınma denklemini sağlam bir zemine oturtarak komşu ülkelerle yavaş yavaş ilişkilerini düzeltmeye yönelmesi ekonomik açıdan ticaret ve yatırımcı ilişkilerine pozitif yansımıştır. Böylece, Türkiye pazarlarını çeşitlendirmiş, komşu ülkelerle yapmış olduğu ticaretin hacmini arttırmıştır. "Hükümetin Ortadoğu ve Afrika'ya yönelik açılımları Türkiye'nin bu ülkelerle olan ticari ilişkilerinin gelişmesini de sağlamıştır. Değişen dengeler sonrasında, Türkiye'de dış politika kararları ekonomi ile uyumlu biçimde uygulanmaya başlamıştır. Hükümetin Ortadoğu ve Afrika'ya yönelik açılımları Türkiye'nin bu ülkelerle olan ticari ilişkilerinin gelişmesini de sağlamıştır. Bu açılımlar dış ticarette eksen kayması olarak tartışılsa da esasen bu açılımların dış ticarette ülke çeşitliliğini arttırdığı görülmüştür. Bu çeşitliliği artırmaya yönelik yap1lan serbest ticaret anlaşmaları ve vize muafiyetleri gibi uygulamalar 
Türkiye ekonomisinin diş ticaretteki eksen genişlemesi olarak adland1rılmalıdır. Dış ticaretteki eksen genişlemesi Latin Amerika, Afrika, Ortadoğu ve Balkanlar bölgeleri ile Rusya ve Çin gibi ülkelerle ticari ortaklıkların yapılması ve karşılıklı ekonomik çıkar sağlanması 1990’larda başlayan küresel ölçekli değişim trendi ile paralel bir görünüm arz etmektedir. Türkiye de gelişmekte olan ülkeleri yükselişe geçiren küresel ölçekli bu değişimi doğru izleyen bir yaklaşımı benimseyerek istikrarlı ekonomik görünümü ile etkin bir dış ticaret politikası izlemiştir (Karagöl, 2013: 75-76)".

1980'li yıllara kadar Türkiye belli küçük bölgelere sıkışıp kalmıştır. 80’li yıllardan sonra Anadolu'daki yerel dinamikler harekete geçirilerek girişimci/yatırımcı potansiyeliniarttırma stratejisi AK Parti hükümetiyle büyük bir ivme kazanmış ve hava, kara ve demiryollarıyla doğu-batı birbirine bağlanmıştır. Komşu ülkelerle ilişkilerin düzelmesi hem ticaret potansiyelini arttırmış hem de pazarı çeşitlendirmiştir. Bu açılımlar üzerinden Türkiye’nin Soğuk Savaş dönemi alışkanlıklarını terk ederek borç kapanından kurtulma noktasına gelmesi başta komşu ülkeler ve İslam dünyası olmak üzere değişik coğrafyalarla farklı düzlemlerde ilişki kurmasının önünü açtı̆̆ gibi etki alanını da genişletmiştir. Siyasal istikrarın oluşturmuş olduğu güven ortamı sayesinde yabancı sermaye girişleri hızlanmış, 1950- 2002 arası dönemde toplamda 13,5 milyar dolar olan yabancı yatırım miktarı, 2002 yılında 617 milyon dolar iken, bu miktar 2007 yılında 22.047 milyar dolar seviyesine çıkmıştır. 2008 yılında ise küresel ekonomik krizden diğer ülkelere nispeten daha az etkilenmiştir fakat doğrudan yabancı yatırım oranlarında düşüş gerçekleşmiştir. 2009 yılında ise ekonominin finansal altyapısı ve şoklara karşı dirençli yapısı ile doğrudan yabancı yatırım miktarı yeniden artışa geçmiştir. Türkiye son 9 yılda 110 milyar Dolar doğrudan yabancı yatırım çekmiş ve kurumsallaşan ekonomisi sayesinde de 2012 yılı için doğrudan yabancı yatırım açısından dünyanın en cazip 13. ülkesi olmayı başarmıştır (Karagöl, 2013: 70).

“İnsanlığın büyük bölümü ve tarihin en uzun devreleri için tipik devlet modeli, imparatorluklardır. İmparatorluklar, uluslararası sistem 
içinde hareket etmeye ilgi duymazlar. Bizzat kendileri uluslararası sistem olma çabası içindedirler. İmparatorlukların güç dengesine gereksinimi yoktur (Kissinger, 2009: 13)”.20. İmparatorluk mirası üzerine kurulan Türkiye'nin sıradan ulus-devletler gibi bir dış politika yürütmesi beklenmemelidir. Davutoğlu'nun ifadesiyle söyleyecek olursak; "Dış politikada takip etmemiz gereken temel ilke firmflexible olması gerekir. Yani ne istediğini bilen, kararlı (firm) ve bunu talep ederken ya da karşı tarafla müzakere ederken alabildiğince esnek (flexible) olmalıdır. Türkiye, bu ilkeyi uygularsa, dışarıdaki Türk imajı büyük ölçüde değişecektir. Bu meseleyi bir örnek üzerinden şöyle anlatabiliriz: Bir insan düşünün ki adalesi çok güçlü, midesi çok zayıf, beyni küçük ve az üretiyor, kalbi zayıf. Adalenin sıkı durması için midenin beslenmesi gerekiyor; ama mide zayıf olduğu için bunu yapamıyor ya da beyin adalenin nasıl kullanılması gerektiği konusunda yeteri kadar alternatif üretemiyor ve kalp adalenin gücünü taşıyamıyor. Bu analoji üzerinden Türkiye’ye şu şekilde bakılabilir: Çevresindeki faktörlerden dolayı askeri gücü yüksek olmalı (adale); fakat askeri gücün doğru bir şekilde işleyebilmesi için hem ekonomik istikrara (mide) sahip olmalı, hem de üniversiteler, fikir adamları (beyin) sürekli yeni fikirler/alternatifler üretmelidir. Bunlara ilaveten de kendisine güveni/özgüveni (kalp) sağlam olmalıdır (2013: 117)”. Türkiye, son yıllarda önemli miktarda kalkınma yardımlarında bulunarak İslam dünyasıyla olan ilişkilerini güçlendirme yoluna gitmiştir. "Kalkınma yardımlarının ülkeler arasında ticari işbirliğinin arttırılmasında çok önemli payı vardır. Ayrıca, teknik iş birliği çalışmaları ile sosyal ve ekonomik alt yapılar ve üretim sektörlerinin geliştirilmesi sağlanarak, iki ülke arasında yatırımlar için elverişli ortamlar temin edilmiştir. Türkiye'nin resmi kalkınma yardımı hacmi küresel ekonomik krize rağmen, 2009 yılında 707 milyon dolara, 2010 yılında 967 milyon dolara ve 2011 yılında ise 1.2 milyar dolara ulaşmıştır. Türkiye, OECD ülkeleri arasında da kalkınma yardımları miktarını en fazla arttıran ülke olmuştur (Karagöl, 2013: 78)”.

Refah seviyesinin artması ülkelerin ve milletlerin kendilerine ve birbirlerine olan özgüvenlerinin de artmasını beraberinde getirmektedir. Mesela; Soğuk Savaş döneminde Rusya'yla çok sınırlı oranda siyasi ve 
diplomatik ilişki kuran Türkiye; Soğuk Savaş sonrası dönemde işi iki ülke arasında vizeleri kaldırmaya kadar götürmüştür. Benzer durum daha önce Irak'la ve iç savaş öncesi dönemde Suriye'yle de yapılmıştır. Bütün bunlar birlikte düşünüldüğünde Soğuk Savaş dönemi reflekslerine göre Avrupa Birliği ve ABD arasında gelgitler yaşayan Türkiye’nin,yeni dönemde kalkınmanın verdiği özgüvenle bir yandan alternatiflerini çoğaltırken diğer yandan da öncelikli olarak Soğuk Savaş döneminden kalma komşularıyla olan yabancılaşma problemini çözmeye yöneldiği görülmektedir. Türkiye’nin komşularıyla kendi önceliklerine göre ilişki kurmaya yönelmesi bir yandan kendine ve siyasal sistemine olan güvenini arttırırken diğer taraftan da komşu ülkelerle ekonomik, kültürel, siyasi, diplomatik, vb. düzlemlerde ilişki kurmasına imkân sağlamıştır. Süreç içerisinde söz konusu kanalların özellikle ticaret üzerinden genişlemeye başlaması Türkiye’nin 19.yüzyıldan beri yabancılaşmaya başladığı, tarihi ve kültürel mirasıyla buluşmasının imkânlarını çoğaltmıştır.

Kapitalizm, Wallerstein'de belirttiği gibi büyük siyasal organizasyonlardan hoşlanmaz. Dahası bugün bir dünya sistemi haline gelmesini büyük siyasal organizasyonları parçalama yeteneği göstermesine borçludur. Strateji gereği çevresiyle bütünleşme eğilimine giren ülkelerin siyasal istikrarsızlık ortamına doğru itilerek finansal bağımlılık ve borçluluk ilişkileri üzerinden kalkınmalarının sürekli baskı altına alınması politikasını gütmektedir. Bu yaklaşım Türkiye geneline, Türkiye'nin komşularıyla ve İslam dünyasıyla olan ilişkilerine uyarland1ğında meselenin mahiyeti daha iyi anlaşılacaktır. Komşularıyla mukayese edildiğinde Türkiye’nin, demokrasiyle yönetilen tek ülke olması, coğrafya, nüfus, tarihsel miras, mekan, kültür, din, vb. faktörlerin koordinasyonunun yarattığı sinerji, Türkiye'nintoparlayıcılık misyonunun artmasını, İran, Irak, Suriye, Libya, Mısır vb. ülkeler nezdinde etki alanını genişletecektir. Toparlayıcılık misyonunun beraberinde getirdiği özgüven, KürtSorununun çözümünde inisiyatif alarak daha güçlü adımlar atma ihtimalini arttırmıştır. Siyasal istikrar ve ekonomik güven ortamı sonucunda oluşan refah artışı, Kürt Sorunu ve Alevilik probleminin demokrasi çerçevesinde çözülmesi ihtimalini güçlendirmektedir. Dolayısıyla, zamanlama açısından Gezi Parkı Eylemlerinin, Kürt 
Sorununun çözümünde Türkiye'nin tarihindeki en güçlü inisiyatifleri almaya yöneldiği bir döneme rastlaması tesadüfi bir durum olarak değerlendirilmemeli.

Demokrasi, belli aralıklarla halkın seçmiş olduğu yöneticileri geri çağırdığı bir yönetim sistemidir. İktidarın seçimle/seçimde değiştirilmesinin önünün açık olması ve olası bir siyasi istikrarsızlık durumundan ekonominin olumsuz etkilenmesi ihtimaline karşı, gelişmiş ülkelerde demokrasi dışı iktidar arayışlarına prim verilmez. Mesela; ABD, İngiltere, Almanya vb. gelişmiş ülkelerde de eylemler olmakta, protestolar düzenlenmekte ama onların hiçbiri Türkiye'de olduğu gibi siyasi bir krize dönüşmemekte, siyasal iktidarın yönetme meşruiyetini tartışmaya açmamaktadır. Dünya ölçeğine baktı̆̆ımızda demokrasisi en güçlü olan ülkelerin kişi başına düşen milli gelirleri en yüksek olan ülkeler olması tesadüf değildir. Türkiye'de 2002'de kişi başına düşen GSYH miktarı 3.492 dolar iken, 2011'de bu miktar 10.469 dolar seviyesine yükselmiştir. Türkiye 2013-2015 döneminde OVP'de kişi başına düşen geliri 2015 y1lında 12.859 Dolar’a yükseltmeyi ve yüksek gelirli ekonomiler grubuna girmeyi hedeflemektedir (Karagöl, 2013: 13). Türkiye'nin yüksek gelirli ülkeler kategorisine yükselmesi bu tür eylemlerin siyasal iktidarı tehdit etme potansiyelini azaltacaktır.

Modern toplumda, geleneksel toplumlarda olduğu gibi cenaze ritüelleriyoktur. Tıpkı olası bir trafik kazasında kaza yapan araçların trafiği tıkamasına yol açmaması için ivedilikle yoldan kaldırılması gibi gelişmiş ülkelerde de bu tür sosyal hareketlerin demokrasinin işleyişini sekteye uğratmasına müsaade edilmemektedir. Ülke zenginleştikçe,“mevcudu muhafaza etme anlamında" insanlar muhafazakârlaşmakta ve tavırlarını refahtan yana koymaktadırlar. Demokrasinin beraberinde getirmiş olduğu refah artışının antidemokratik yollardan sekteye uğratılmasına prim vermemektedirler. Siyasal iktidarın yönetme meşruiyetinin tartışılmadığ 1 demokratik ülkelerde, ekonomik dengeler kolay bir şekilde bozulmadığından hem siyaset kurumuna hem de piyasalara olangüvende bir azalma olmamaktadır. Demokratik toplumlar gerek finansal, gerek enformasyonel ve gerekse de ekonomik açılardan para, 
bilgi ve mal giriş-çıkışlarına açık olduklarından aynı zamanda çok hassas toplumlardır.Friedman'ın(2003: 135) ifadesiyle söyleyecek olursak demokrasilerde vatandaşlar belli periyotlarla oy verirken piyasalar hükümetlerin ve ülkelerin politikalarını her gün defalarca oylamakta, bütün bunların sonucunda ise hükümetler/ülkeler ödüllendirilmekte ya da cezalandırılmaktadırlar.

Kapitalizm için istikrarsızlık ve belirsizlik ortamları son derece mümbit ortamlardır. Siyasal belirsizlik ihtimalinin yükselmesi durumunda ilk etapta sermaye çıkışları/kaçışları ile hükümetler uyarılmakta, krizin derinleşme eğilimine bağlı olarak bu uyarının sertlik derecesi artmakta ve bütün bunlaryatırım ortamınıpozitif veya negatif yönde etkilemektedir. Kapitalistler rekabet etmekten hoşlanmazlar. Serbest piyasadan almak isterler ama tekel fiyatından satmak isterler. Çünkü piyasada en yüksek fiyat tekel fiyatıdır. Çalışmanın giriş kısmındakitwitlerden de anlaşılacağ yandan seçilmiş hükümetin yönetme meşruiyetinin tartışmaya açılması diğer yandan ise bunun güven ve yatırım ortamını olumsuz etkilemesiyle siyasi kriz, ekonomik krize tahvil edilerek daha da derinleştirilmek istenmektedir.

Örgütlü olarak sermaye çıkışlarının artması durumunda, sermayeyi geri çağırmak için faizlerin yükseltilmesisiyasal krizi daha da derinleşecektir. Faiz oranlarının kapitalistlerin arzu ettikleri seviyeye yükseltilmesiyle denge yeniden kurulacaktır. Böylesi bir ortamda olası bir kriz durumuyla karşı karşıya kalan ülkelerin yapması gereken şey; faiz oranlarını yükselterek kaçan sermayeyi geri çağırmaktır. Sermaye; kriz öncesi döneme göre daha yüksek bir faiz getirisi vaadiyle geri çağrıldığından devlet ve dolayısıyla halk üzerindeki faiz/ci baskısı artmaktadır. Yatırım-üretim-istihdam-tüketim bundan olumsuz etkilenmekte ve ekonomik dengeler faiz/ci lehine bozulmaktadır. Mesela; Şubat 2001'de yaşanan siyasi krizin piyasalara yansıması, dövize yönelik spekülatif hareketlerin başlamasına ve hazinenin Aralık 2000' de yüzde 65 seviyesinde borçlanırken, Şubat 2001'de yüzde 144 faizle borçlanmasına yol açmıştır (Karagöl, 2013: 77).Bu tür krizler üzerinden kapitalistler adeta 
karabasan gibi devletlerin ve milletlerin üzerine çökerek hegemonyalarını devam ettirmektedirler. Gezi Parkı Eylemlerine bizzat açıktan destek veren finans sektörü ve sermaye grubu temsilcilerinin çıkışlarını bu çerçevede değerlendirmek gerekmektedir.

Ekonomik açıdan Gezi Parkı Eylemleri öncesinde gelinen ekonomik seviyeye bakıldığında; Merkez Bankası (TCMB), bankaların Kredili Mevduat Hesaplarına (KMH) önemli bir sınırlandırma getirmiş ve burada uygulanabilecek tavan faiz oranını yüzde 2.2 olarak belirlemiştir. Bu karar öncesinde bankaların uyguladığı oran ise aylık yüzde 5’lere kadar çıkmaktadır. Hükümet uygulamış olduğu politikalarıyla Cumhuriyet tarihinde finans oligarşisine karşı en büyük darbeyi vurmuştur (Ertem ve Eseyan, 2013: 40). Fakat eylemleri takip eden gün ve haftalarda Merkez Bankasının faiz oranlarını yükseltmesiyle millet aleyhine denge yeniden kurulma yoluna gidilmiştir.

Faiz oranlarının yükselmesi yatırım maliyetlerini arttırmaktadır. Pahalıya kredi kullanma (para da dâhilüretim artışını sağlayacak hammaddeyi daha pahalıya satın alma), düşük ücretle çalışma ve pahalıya ürün tüketmeyi beraberinde getirdiğinden refah seviyesinde gerilemeye ve yoksulluğun artmasına yol açmaktadır. Enflasyonist ortam sermaye sahiplerinin doğrudan yatırım yapması için risklidir. Çünkü yüksek enflasyonist ortam düşük enflasyonist ortama göre faizi son derece cazip bir gelir kaynağı hale getirdiğinden sermaye sahipleri paralarını yatırıma değil faize yatırmaktadırlar ki bu tamda kapitalistlerin arzu ettikleri bir durumdur. Çünkü pozitivist eğitim anlayışın bir sonucu olarak ekonominin iktisattan ayrılması; onun aynı zamanda ahlaki ve sosyal kaygılardan arındırılmasını da beraberinde getirmiştir. Böylece arz-talep denklemi çerçevesinde faizin meşruiyeti de sağlanma yoluna gidilmiştir.

Yüksek faiz oranlarına düşük istihdam ve yatırım oranları eşlik ettiğinden hayat pahalılığı artmakta ve bunlara bağlı olarak halkın hükümete yönelik tutumu negatife dönerek hükümete olan güvenin azalmasına yol açmaktadır. 1994 ve 2001 krizleri sonrasında gerçekleştirilen ilk seçimlerde hükümet değişiklikleri bu çerçevede düşünebilir. Gezi 
Parkı Eylemleri özelinde düşünüldüğünde, Türkiye'de kriz varmış gibi bir havanın estirilmesinin ekonomide yarattığı dalgalanmaya bakılırsa;BİST'in $91.000{ }^{\prime} \mathrm{den}^{20} 63.000^{\prime} \mathrm{e}^{21}$, dolarin $1,84^{\prime} \mathrm{den}^{22} 2,22^{\prime} \mathrm{ye}^{23}$, euronun $2,23^{\prime}$ den $^{24} 3,10^{\prime} \mathrm{a}^{25}$ varan bir değişim gösterdiği görülmektedir. Aslında bu adı konulmamış kısmi bir devalüasyondur. Piyasa kuralları çerçevesinde düşünüldüğünde bu kur ve faiz artışından dövizi olanlar ve faiz geliri elde edenler karlı çıkar. Budurum eşitsizliğin artmasına, geniş toplumsal kesimlerin yoksullaşmasına ve onlar üzerindeki sömürü yükünün ağırlaşmasına yol açmaktadır. Bütün bunları bir araya getirip topladığımızda üretimde daralmanın beraberinde getirmiş olduğu refah azalması demokrasinin geleceği ve derinleşmesi için son derece riskli bir ortam yaratmaktadır. Bu tür eylemler üzerinden hükümetlere/devletlere şoklar verilerek ekonomik dengelerin bozulması ülkelerin kırılganlık derecelerini göstermesi açısından önemlidir. Fakat seçim atmosferinin sağladığı motivasyon nedeniyle şimdilik bu durumun ciddi bir krize yol açmadan tolere edilmeye çalışıldığı söylenebilir. Yukarıda da belirttiğimiz gibi refah seviyesindeki artışın gelir dağılımındaki adaletsizliği "bastırmasının" bir sonucu olarak halkın siyasete olan ilgisinin ve hükümete olan desteğinin artarak devam ettiği, seçimin sağladığ 1 motivasyonla ekonomik krizin çok fazla hissedilmediği söylenebilir.

İster demokrasi isterse de totalitarizmle yönetilsin hiçbir siyasi iktidar ekonomik dengelerin bozulmasını istemez. Demokrasi, yapılması gerekenleri halkın rızasını alarak, halkla birlikte yapma esasına dayanmaktadır. Burada iktidarın halkla çatışmasından ziyade bütünleşmesi esastır. Dolayısıyla halk nezdinde güvenilirliğini ve inandırıcıllğını kaybeden bir siyasi iktidarın meşruiyet zemini aşınmıştır. Weber'yen ifadeyle söyleyecek olursak; hükümet yasal olarak meşru otoriteyi temsil etse de halk onun meşru olduğuna dair inancını kaybettiyse bu onun meşru olduğunu göstermez. "Bir normun ideal olarak kabul edilmesi, 
ortak ilgilerindeki eylem sorunlarını düzenlediği için tüm ilgililerin onayını kazandığı anlamına gelir (Habermas, 1996: 115)”. Çünkü sosyolojik anlamda meşruiyet ile hukuki anlamda meşruiyet tamamen birbirinden farklıdır. Sosyolojik anlamda iktidarın meşruiyet zeminini kaybetmesi, iktidar açısından siyasal bir kriz durumuna karşılık gelmektedir. Türkiye'nin; başta Kürt Sorunu olmak üzere, Kanal İstanbul, Nükleer Santraller ve İstanbul'a Üçüncü Havalimanı gibi büyük siyasi ve ekonomik projeleri hayata geçirmeye çalıştığ den siyasal motivasyonun bozulmak istenmesi KONDA ve GENAR'in yaptıkları araştırmalarda eylemlere destek verenlerin ağırlıklı olarak sol kesimden oluşması normal bir durum olarak algılanmamalıdır.

\section{Sonuç}

Avrupa merkezli tarih anlayışı üzerinden bir okuma yapıldığında ortaçağdan itibaren dünyanın siyasal bütünleşmeye, Asya merkezli bir tarih anlayışı üzerinden okuma yapıldığında ise siyasal parçalanmaya doğru bir değişim süreci geçirdiği görülmektedir. 19. ve 20. yüzyıllarda dünyada yaklaşık olarak otuz civarında belli başlı büyük siyasal organizasyon varken, 21. Yüzyılın ilk çeyreğinde bu sayının 250'ye yaklaştığı görülmektedir. Günümüz dünyasında beş bin civarında etnisitenin varlığını sürdürdügü düşünüldüğünde, temsil edilmeyen bu halklardan sadece bir kısmının siyasi bağımsızlık ya da özerklik taleplerinin meşru kabul edilmesi durumunda bu siyasal parçalanma sürecinin çok hızlı bir şekilde siyasal çözülmeye doğru evrileceği muhakkaktır. Bu durumda insanlığın kabile devletleri çağına doğru yol aldığı söylenebilir. Avrupa merkezli tarih anlayışı üzerinden bir okuma yapıldığında bu durumun sarkacın geri salınmasına, dünyanın ulus-devlet öncesi prenslik, düklük, krallık, gibi küçük siyasal organizasyonlar dönemine tekrar geri dönmesine karşılık gelmektedir. Sürekli bölünmüş bir dünyanın, şiddetin hüküm sürdüğü bir dünya ihtimali olması büyüktür.

Kapitalist sistem doğası gereği güçlü devlet tekelleri olmadan işleyemez. Kapitalistler serbest piyasadan almak isterler ama serbest piyasaya satmak istemezler. Çünkü piyasada en yüksek fiyat tekel fiyatıdır. 
Bütün kapitalist sistemlerde pazar/lar, belli kişi veya gruplar tarafından adeta parsellenmiştir. Mesela; sektörelbazda dünya ekonomisine bakıldığında; bankacılık, sigortacılık, otomotiv, iletişim, havayolu taşımacılığı, bilgisayar, gazlı içecekler, vb. pazarların belli aktörler arasında bölüşüldüğü ve herhangi bir yeni aktörün piyasaya girebilmesi için devletlerin kendi aralarında kıran kırana mücadele ettikleri görülmektedir. Merkantilist dönemde sömürgecilik üzerinden kalkınmanın faturasını sömürge ülkelerine tahvil eden kapitalizmin merkez ülkelerinin; bugün liberalizm adı altında Dünya Ticaret Örgütünün (DTÖ) öncülüğünde serbest ticarette dayatmaları azgelişmiş ülkeler açısından dezavantajlı bir durum teşkil etmektedir. Sportif bir ifadeyle söyleyecek olursak bu durum, ağır sıklet olan bir güreşçinin serbest güreşte ısrar etmesine karşlık gelmektedir.

Mesela; üçüncü köprünün yapılmaması, üçüncü havalimanının yapılmaması, nükleer santrallerin inşa edilmemesi, Kanal İstanbul gibi projeler, toplumun geleceği açısından düşünüldüğünde iktidarın meşruiyetini azaltıcı değil aksine arttırıcı bir etkiye sahip olmalıdır. Bunların uzun vadeli etkileri/getirileri düşünüldüğünde Türkiye’nin gelişimine yansımalarının olumlu olacağı açıktır. Diğer bir ifadeyle bu yatırımlardan vazgeçmek, ihtiyaç duyulan bu hizmetleri başkalarından almayı zorunlu kılmaktadır. Bu tür ihtiyaçları temin etme pozisyonunda olan ülkelerin belli lobiler üzerinden bunların hayata geçirilmesini engellemeye çalışmaları kendi milli çıkarları açısından doğru bir yaklaşımdır. $\mathrm{Bu}$ tür yatırımların ülkede refah seviyesinin artışına ve demokrasinin güçlenmesine etkisi pozitif yönde olacaktır. Türkiye, enerjide dışa bağımlı bir ülkedir. Sadece nükleer santraller üzerinden düşünüldüğünde ekonomik büyümenin sürdürülebilirliği enerji tedarikinin sürdürülebilirliğine bağlıdır. Türkiye mevcut büyümesini kur baskısı ve enerji ithalatı gibi iki büyük ağırlıkla birlikte sağlamak gibi büyük bir problemle karşı karşıyadır. Enerjide dışa bağımlılığın azalması Türkiye'nin uluslararası piyasalarda rekabet gücünün artmasına karş11ı gelecektir. Dünyada enerjide dışa bağımlılı̆g 1 azaltan ekonomilerin küresel piyasalardaki rekabet gücü artmaktadır. 
Moderniteyle birlikte Avrupa'nın kendi lehine bozmuş olduğu bu dengenin, 20. yüzyılın ikinci yarısından itibaren Asya’nın toparlanma sürecine girmesiyle 21. yüzyılda dengenin yeniden kurulmaya çalışıldığı, Paris, Londra, Berlin ve Washington'un irtifa kaybederken Pekin, Tokyo, Yeni Delhi gibi merkezlerin ön plana çıtığg görülmektedir. Dünya ekonomisinin İpekyolu güzergâhına doğru kayması Türkiye vb. bölge ülkelerinin etki alanını genişletecektir.

Dünya, demokrasilerin birbirleriyle savaş yapmadığı ve barışın demokratik kurumların gelişmesine bağlı olduğu bir yöne doğru gitmektedir. Türkiye’nin, kalkınmada kapitalizmin merkez ülkelerinin seviyesine yaklaşması durumunda Gezi Parkı türü eylemlerin siyasal motivasyonu bozucu etkisi azalacaktır.Türkiye'nin ekonomik kalkınmayla birlikte demokrasisini güçlendirmesi etki alanı genişletecektir. Aksi durumda, siyasal istikrarsızlığın ekonomik istikrarsızlığı besleyeceği/tetikleyeceği düşünüldüğündebu durum Türkiye’nin 1990’lı yıllarda olduğu gibi koalisyon hükümetleri dönemlerine geri dönerek demokrasisinin güdük kalmasına yol açacaktır. Gezi Parkı Eylemlerinin bazı siyasi manevralarla ekonomik krize dönüştürülmeden geçiştirilmesi demokrasinin kazandığı esneklik derecesini göstermektedir. 


\section{Kaynakça}

Anderson, Benedict (2007). Hayali Cemaatler, Çev. İskender Savaşır, Metis Yayınları, İstanbul.

Avcıŏlu, Doğan (2006).Türkiye’nin Düzeni, Cilt: I, Tekin Yayınevi, İstanbul.

Berkes, Niyazi (2006). Türkiye'de Çağdaşlaşma, Yay. Haz. Ahmet Kuyaş, Yapı Kredi Yayınları, İstanbul.

Braudel, Fernand (2004).Maddi Uygarlık, Dünyanın Zamanı, Çev. Mehmet Ali Kılıçbay, İmge Kitabevi, Ankara.

Davutoğlu, Ahmet (1999).“Tarih İdraki Oluşumunda Metodolojinin Rolü: Medeniyetlerarası

Etkileşim Açısından Dünya Tarihi ve Osmanlı”, Divan, Yıll:4, Cilt:2, Sayı: 7.

Davutoğlu, Ahmet (2002).“İslam Dünyasının Siyasî Dönüşümü: Dönemlendirme ve Projeksiyon”, Divan, Y1l: 7, Cilt: I, Sayı: 12.

Davutoğlu, Ahmet (2003).Stratejik Derinlik, Küre Yayınları, İstanbul.

Davutoğlu, Ahmet (2013). Teoriden Pratiğe, Küre Yayınları, İstanbul.

Ertem, Cemil ve Eseyan, Markar (2013). Dünyayı Durduran 60. Gün, Etkileşim Yayınları, İstanbul.

Ferro, Marc (2011).Sömürgecilik Tarihi, Çev. MunaCedden, İmge Kitabevi, Ankara.

Friedman, Thomas (2003).Küreselleşmenin Geleceği, Çev. Elif Özsayar, Boyner Yayınları, İstanbul.

Gökalp, Emre (2009). “Toplum ve Kültür”, Sosyolojiye Giriş, Ed. Nadir Suğur, Anadolu Üniversitesi Yayınları, Eskişehir.

Habermas, Jürgen (1996). İletişimsel Eylem Kuramı, Çev. Mustafa Tüzel, Kabalcı Yayınları, İstanbul. 
Huntington, Samuel P. (2007). Üçüncü Dalga, Çev. Ergun Özbudun, Kıta Yayınları, Ankara.

Karagöl, Erdal Tanas (2013).Ak Parti Dönemi Türkiye Ekonomisi, SETA Yayınları, Ankara.

Karluk, Rıdvan (2013). "Uluslararası Para Fonu”, Uluslararası Ekonomik Kuruluşlar,Ed. Özgür Tonuş ve Nazım Çatalbaş, Anadolu Üniversitesi Yayınları, Ankara.

Kennedy, Paul (1990).Büyük Güçlerin Yükselişve Çöküşleri, Çev. BirtaneKaranakçı, Türkiye İş Bankası Yayınları, İstanbul.

Kissinger, Henry (2009).Diplomasi, Çev. İbrahim H. Kurt, Türkiye İş Bankası Yayınları, İstanbul.

Luraghi, Raimondo (2000).Sömürgecilik Tarihi, Çev. Halim İnal, E Yayınları, İstanbul.

Mardin, Şerif (2003).Din ve İdeoloji, İletişim Yayınları, İstanbul.

McNeill, William (2008).Dünya Tarihi, Çev. Alâeddin Şenel, İmge Kitabevi, Ankara.

McNeill, William (2011).Avrupa Tarihini Oluşumu, Çev. Yusuf Kaplan, Külliyat Yayınları, İstanbul.

Mumford, Lewis (2007).Tarih Boyunca Kent, Çev. G. Koca ve T. Tosun, Ayrıntı Yayınları, İstanbul.

Ortaylı, İlber (2005).İmparatorluğun En Uzun Yüzyıl, Alkım Yayınları, İstanbul.

Pirenne, Henri (2011).Ortaçă̆ Kentleri, Çev. Şadan Karadeniz, İletişim Yayınları, İstanbul.

Sayar, Ahmed Güner (2013).Osmanli İktisat Düşüncesinin Çağdaşlaşma$s l$,Ötüken Neşriyat, İstanbul.

Smith, Adam (2011).Milletlerin Zenginliği, Çev. Haldun Derin ve Gülten Kazgan, Türkiye İş Bankası Yayınları, İstanbul.

Tilly, Charles (2001).Zor, Sermaye ve Avrupa Devletlerinin Oluşumu, Çev. Kudret Emiroğlu, İmge Kitabevi, Ankara. 
Wallerstein, İmmanuel (2005).Dünya-Sistemleri Analizi, Çev. Ender Abadoğlu-Nuri Ersoy, Aram Yayınları, İstanbul.

Yayman, Hüseyin (2011).Türkiye’nin Kürt Sorunu Hafızası, Doğan Kitap, İstanbul.

Yıldız, Ahmet (2010)."Ne Mutlu Türküm Diyebilene”, İletişim Yayınları, İstanbul.

http://t24.com.tr/files/GeziParkıFinal.pdf (Erişim Tarihi: 08/02/2013).

http://www.genar.com.tr/files/GEZIPARKI_PROFIL-SON.pdf (Erişim Tarihi: 08/02/2013).

http://file.setav.org/Files/Pdf/20130916162138_kurguilegerceklikarasindagezieylemleri_rapor (Erişim Tarihi: 08/02/2013).

http:/www.sde.org.tr/userfiles/file/SDE\%20Taksim\%20Gezi\%20Parkı\%20 Raporu\%20Haziran202013.pdf (Erişim Tarihi: 08/02/2013).

http://tusivar.com/wp-content/upşoads/2013/09/BURSA-GEZİ-PARKI-ARAŞTIRMASI-pdf.pdf (Erişim Tarihi: 08/02/2013).

http://tasav.org/usr_img/yayinlar/analiz/analiz_4_shy_4_gezi_parki_ylGIt_son.pdf (Erişim Tarihi: 08/02/2013).

http://www.ikv.org.tr/images/upload/data/files/ikv_degerlendirme_notu73.pdf (Erişim Tarihi: 08/02/2013).

http://istanbul.mazlumder.org/webimage/gezi-parki-raporu-2013.pdf (Erişim Tarihi: 08/02/2013).

http://www.orsam.org.tr/tr/trUploads/Yazilar/Dosyalar/201372_oanaliztemmuzder.pdf (Erişim Tarihi: 08/02/2013).

http://dibakgenc.org/wp-content/uploads/2013/09/Gezi-Park...pdf (Erişim Tarihi: 08/02/2013).

http://www.amnesty.org.tr/ai/system/files/GeziParkiTR.pdf (Erişim Tarihi: 08/02/2013).

http://www.psikolog.org.tr/assets/file/pdf/DIRENTPD.pdf (Erişim Tarihi: 08/02/2013).

http://www.vakifyatirim.com.tr/files/news_27934.pdf (Erişim Tarihi: 14/03/2014). 
http://www.vakifyatirim.com.tr/files/news_14921.pdf(Erişim Tarihi: 14/03/2014).

http://www.tcmb.gov.tr/kurlar/today.html(Erişim Tarihi: 14/03/2014). http://www.tcmb.gov.tr/kurlar/201305/27052013.html(Erişim Tarihi: 14/03/2014).

http://www.tcmb.gov.tr/kurlar/today.html(Erişim Tarihi: 14/03/2014).

Abstract: -Political and Economic Motivation Behind of "Gezi"- Studies performed up till now about Gezi Park actions have generally been handled from the perspective of current reality. However, in this study, from the point of the view that the history hasn't been lived in the same direction by European and Asian societies, Gezi Actions have been tried to be an analyzed with respect to their historical background and profundity. After the World War I, capitalism caused in collapse of imperial political structures and proliferation of the perception of Nation-State. And after World War II, capitalism transformed most of the political dependencies to economic and technological dependencies. It has been seen that, EastWest balance which has been abolished beginning from the Middle Ages, is tried to be reestablished at 21st century depending on recovering of Eastern societies. Turkey's approach to Western standards on development after its "performance" especially after the year 2002; and beginning just after termination of debt liability of Turkey with IMF shows hat the deep motive of Gezi Actions is not "a few trees". Consequently, because of its vitiating impact on political motivation, analysis of Gezi Actions with its historical background may provide us important expansions.

Key words: Capitalism, the Nation-State, Democracy, the IMF, the interest of the Cold War, Asia. 